УДК 37.015.31(477)

DOI:

Анатолій Мартинюк, доктор педагогічних наук, професор кафедри мистецьких дисииплін і методик навчання ДВНЗ “Університет Григорія Сковороди в Переяславі"

\title{
ФОРМУВАННЯ СВІТОГЛЯДУ ТВОРЧОЇ ОСОБИСТОСТІ В УМОВАХ ОСВІТНЬОГО ПРОСТОРУ УКРАЇНИ
}

У статті розглянуто формування світогляду творчої особистості в умовах освітнього простору України. Проаналізовано творча і мистечька діяльність відомих вітчизняних філософів, педагогів, мистецтвознавиів, письменників, музикантів, що вплинуло на формування світогляду творчої особистості в умовах освітнього простору. Узагальнюючи вищесказане, можемо стверджувати, щзо за допомогою науковометодичної спадщини вітчизняних педагогів в освітньому просторі створюється позитивна иіннісна орієнтачія навчання, тобто формується світогляд творчої особистості.

Ключові слова: освітній простір; світогляд; творча особистість; педагог; спадщчина.

Jim. 10.

Anatolii Martyniuk, Doctor of Science (Pedagogy), Professor of the Art Disciplines and Teaching Methods Department, SHEI "Hryhoriy Skovoroda University in Pereiaslav"

\section{FORMATION OF A CREATIVE PERSONALITY'S WORLDVIEW IN THE CONDITIONS OF THE EDUCATIONAL SPACE OF UKRAINE}

In the article it is considered the process of forming of the creative person's worldview in the educational space of Ukraine. The creative and artistic activity of famous domestic philosophers, teachers, art critics, writers, musicians, public figures, which influenced the formation of the worldview of the creative personality, is analyzed. The theoretical and practical aspects of modern pedagogical and art studies are revealed. It is pointed out that the pedagogical heritage of the educational space of Ukraine contributes to the development of educational processes in the system of modern education. Scientific works that have influenced the formation process of a creative personality's worldview in the educational space of Ukraine are an important component of the array of historical and pedagogical research.

It is determined that the heritage of the pedagogical activity of prominent teachers, writers, historians, philosophers, musicians, public figures, which contributes to the formation of a creative personality's worldview are relevant today. Researchers emphasize that of particular importance in shaping the worldview of the creative personality is the spread of creative opportunities that need to be formed among students in the process of educational work, namely: imagination, intuition, unconscious components of mental activity and the need for self-actualization. An emphasis is placed on the need for a fundamental study of the historical and pedagogical experience of the past to identify innovative concepts and clarify their role in the development of the modern education system.

Summarizing the information obtained during the analytical research, it is argued that a creative personality's worldview formation in the educational space of Ukraine involves the traditional pedagogical experience of prominent artists, which contributes to the development and transmission of the heritage of pedagogical education and culture. With the help of scientific and methodological heritage of domestic teachers in the educational space, a positive value orientation of learning is created, i.e. a creative personality's worldview is formed.

Keywords: educational space; worldview; creative personality; teacher; heritage.

П остановка проблеми. На сучасному етапі актуальною постає проблема гармонійного, всебічного розвитку особистості в умовах освітнього простору України. Процес формування творчої особистості неможливий без фундаментального дослідження історико-педагогічного досвіду минулого для визначення інноваційних концепцій і з'ясування їх ролі у розвитку сучасної системи освіти. Особливий вплив на перетворення освітнього простору України набуває розв'язання теоретичних й практичних аспектів мистецтвознавчих та педагогічних досліджень, а саме: процесів розвитку національного мистецтва, музично-педагогічної спадщини вітчизняних педагогів, навчальновиховні процеси закладів вищої освіти.

Аналіз останніх досліджень і публікацій. Традиційний процес формування світогляду творчої особистості в умовах українського освітнього простору розглядали відомі філософи, педагоги, мистецтвознавці, письменники, музиканти, громадські діячи, а саме: М. Березовський, Д. Бортнянський, П. Грінченко, М.Драгоманов, Ф. Колесса, М.Лисенко,М. Леонтович, 


\section{ФОРМУВАННЯ СВІТОГЛЯДУ ТВОРЧОЇ ОСОБИСТОСТІ В УМОВАХ ОСВІТНЬОГО ПРОСТОРУ УКРАЇНИ}

Н.Нижанківський, О. Русова, Г. Сковорода, Леся Українка, Т. Шевченко, Б. Яворський та ін.

Поняття “освітній простір” досліджуваної проблеми розглядають Г. Бутенко, А. Евтодюк, О. Леонова, Н. Рибка, А. Цимбалару та інші; вагомий внесок був зроблений представниками педагогіки і психології, які досліджували проблему творчого мислення: Б. Ананьєв, Дж. Гілфорд, Дж. Піаже, А. Рахімов, З. Фройд та інші; питання формування творчої особистості, педагогічні умови і особливості їі діяльності висвітлюють такі дослідники: Є. Антонович, Г. Буш, І. Глинська, Л. Гармаш, С. Желєзняк, О. Ковальов, О. Леонтьєва, Н. Ляшова, Ж. Марчук, Л. Масол, Я. Пономарьова, Г.Полякова, В. Рагозіна, С. Рубінштейн,О. Тихомирова, Л.Фесенко П. Якобсон, Л. Яценко та інші.

Отже, метою статті $\epsilon$ висвітлення формування світогляду творчої особистості в умовах освітнього простору України.

Виклад основного матеріалу. Сучасні умови пов'язані з величезним прагненням людини до синтезу буття і культури, покликані суттєво удосконалити спосіб ії життя, підняти її свідомість на якісно новий рівень. Реалізація цих історично закладених пропозицій можлива лише через освіту.

У світовому просторі життєвий і освітній процеси відрізняють рівнозначну роль у ціннісносмисловому аспектах. Життя людини стає важливою частиною і умовою освіти, яке осмислюється як спосіб буття у світі і набуває ознак просторовості, поширюючи межі фізичної й інтелектуальної досяжності світу. Отже, освітній простір формує здатність до організації життя, соціуму, культури, тобто світогляд кожної особистості.

Тлумачення поняття “освітній простір” надає видатний теолог, педагог, письменник Я. Коменський, який наголошує на тому, що освітній простір повинен будуватися, з одного боку, як певний розподіл наукового знання, $з$ іншого - як чітка система шкіл. Видатний педагог стверджував, що “мистецтво навчання не потребує нічого іншого, окрім майстерного розподілу часу, предметів, методу" [3, 46]. Отже, педагогічні ідеї Я. Коменського стали поштовхом до перетворення педагогіки на самостійну галузь із власним методологічним апаратом, сприяли зміцненню системного, наукового підходу до педагогічної проблематики.

Доведено, що освітній простор, в якому відбувається формування світогляду творчої особистості, становить фундаментальну позицію у структурі культури, що динамічно розвивається. 3 цього приводу сучасний філософ В. Кремень визначає світогляд як “своєрідну інтегративну цілісність знань і цінностей, розуму і почуття, інтелекту і дії, критичного сумніву і свідомої недосконалості" [4, 17-18].

Історичні факти свідчать, що на процес формування світогляду творчої особистості впливає досвід фундаторів у галузі національної освіти, відображений у вітчизняних джерелах, який забезпечує об'єктивність наукових висновків й аргументації щодо витоків, структури, змісту формування світогляду творчої особистості. У зв'язку з цим схиляємось до думки науковця Ю. Кузьменко, що “у пошуках нових шляхів вирішення проблем гуманізації виховання та навчання, відповідності рівня освіченості до вимог ринку праці, сучасна педагогічна наука звертається до різних джерел, зокрема, до педагогічного досвіду прогресивних педагогів минулого. Їх педагогічна спадщина зберігає дієвість і в умовах розбудови сучасної національної школи, а творче використання допомагає вчителям виховувати і навчати молодь" [5, 215].

Вагому роль у процесі формування світогляду творчої особистості в умовах освітнього простору України відіграла концепція П. Юркевича, яка залишається недостатньо вивченою і мало задіяною в сучасний культуротвірний процес. Мислитель створив свій варіант філософської антропологічної системи, якій дослідники його творчості дали назву “філософія серця” [9, 189]. Педагогічна теорія П. Юркевича, сформульована на засадах Істини, Добра, Краси, Гармонії, є органічним продовженням його філософськоантропологічного вчення. Тобто він розглядає людину як само цінну особистість, яка розвивається за вічними законами і нормами. 3 цього приводу дослідник I. Юрас зазначає, що "мету виховання можна сформулювати на основі врахування “трьох начал виховання": особливостей духу вихованця; необхідності виконання ним обов'язку у відношенні до церкви, родини, держави; його майбутнього покликання" $[10,187]$.

П. Юркевич висловлював думку про те, що процес засвоєння знань, в якому створюється певні почуття, переживання, може стати великою енергією духовного світогляду людини, тому що процес розвитку особистості тісно пов'язаний зі становленням системи ставлень до дійсності. Таким чином, проаналізувавши творчу спадщину П. Юркевича, можемо стверджувати, що його ідеї філософсько-антропологічного вчення не втратили актуальності і можуть бути використані у формуванні світогляду творчої особистості.

В українській історіографії згадується ім'я М. Корфа, який визнається засновником земської 


\section{ФОРМУВАННЯ СВІТОГЛЯДУ ТВОРЧОЇ ОСОБИСТОСТІ}

В УМОВАХ ОСВІТНЬОГО ПРОСТОРУ УКРАЇНИ

школи, іï організації. Видатний педагог розглядав педагогічні умови формування світогляду творчої особистості, розвиток та вдосконалення навчальновиховного процесу початкової освіти $[1,26]$.

Загальновідомо, що початкова освіта $\epsilon$ найпершою ланкою в системі загальноосвітньої підготовки, в якій формується навчальний потенціал особистості, закладаються духовні та емоційно-вольові якості дитини

М. Корф зумів здійснити комплексний підхід (розробка всіх організаційних та педагогічних аспектів, нормативно-правова база, матеріальне забезпечення, підбір кадрів, контроль і керівництво, підвищення кваліфікації фахівців, взаємодію із соціальним середовищем) до розвитку початкових сільських шкіл у XIX ст. на півдні України.

Отже, науково-методична спадщина М. Корфа, а саме: "Керівництво по навчанню грамоті за звуковим способом", "Наш друг”, “Малятко” і "Наша шкільна справа", "Наші педагогічні питання”, “Керівництво для недільних шкіл”, “Як навчати грамоті дітей і дорослих”, “300 письмових робіт” у сукупності складали вагоме підгрунтя сучасного науково-методичного комплексу забезпечення навчального та виховного процесу, дало можливість збагатити зміст початкової освіти України, спрямувати на формування світогляду творчої особистості.

Дослідження означеної проблеми сприятиме актуалізації в українській науковій діяльності поглядів талановитого педагога, етнографа i фольклориста, бібліографа, мовознавеця, перекладача, критика, освітнього і громадського діяча - Б. Грінченка. Видатний митець особливу увагу надавав знанню української мови як невичерпного джерела педагогічної культури.

Аналізуючи спадщину видатних науковців, які винесли любов до українського народу, його традицій і звичаїв, педагог знаходив це в середовищі простого люду: слухав мелодичну українську мову, збирав етнографічні та лексичні матеріали. У зв'язку з цим Б. Грінченко писав: “Наша мова зветься українською мовою. Наша земля зветься Україною. Свою рідну українську мову ми любимо найбільше од усіх мов на світі... Але ми повинні і других усіх людей любити і поважати. А всім другим людям повинні робити добро" [7, 62]. Особливу роль Б. Грінченко відводить публікаціям етнографічно-фольклорних творів, які містять народний світогляд, показують природні схильності українців, спонукають до любові.

Отже, літературна спадщина Б. Грінченка тісно пов'язані 3 проблемами виховання підростаючого покоління, тобто сприяли формуванню світогляду творчої особистості і подальшому розвиткові української науки і культури.

Науковці зазначають, що важливого значення у формуванні світогляду творчої особистості набуває поширення творчих можливостей, які формуються в учнів у процесі навчально-виховної роботи, а саме: уява, інтуїція, неусвідомлювані компоненти розумової активності, а також потреба в самоактуалізації. Підкреслемо, що творчу особистість ми розглядаємо яктаку, для якої існує мотивація та спрямованість на творчість, що проявляється в органічній єдності 3 високим рівнем творчих здібностей, які дозволяють їй досягти прогресивних, соціально й особистісно значущих результатів у одній або кількох видах діяльності [8].

Варто зазначити, що в наш час простежується інтерес до спадщини митців музичного мистецтва, яка сприяє формуванню світогляду творчої особистості в освітньому просторі України.

Творча діяльність українського композитора, хорового диригента, педагога, громадський діяча, музичного критика К. Стеценка сприяе формуванню світогляду творчої особистості, адже його мистецька спадщина грунтується на створенні і популяризації української культурномузичної платформи на основі національних надбань та світової класики [2]. Саме ця ідея сприяла створенню музичних творів Кирила Григоровича, а саме: митець обирав жанри, пов'язані зі словом, тому хори, обробки народних пісень, кантати та опери складають основу жанрової палітри композитора.

Таким чином, музична спадщина і творча діяльність К. Стеценка впливає на сучасну музичну, виконавсько-хорову та загальнокультурну сфери освітнього простору України.

Формування світогляду творчої особистості в умовах освітнього простору України пов'язане 3 ім'ям видатного музикознавця, педагога, музичного діяча - Б. Яворського.

Наукові дослідження видатного вченого, його методологічні підходи до вивчення музичного мистецтва, створена ним теоретична система ладу зберігають свою актуальність до нашого часу. Глибина і маштабність мислення, системний підхід до вивчення музики, широка джерельна база теоретичних розвідок - ці та інші риси наукової школи Б. Яворського отримали продовження в діяльності наступної генерації українських вчених.

Цінною є думка митця, що процес слухання музики сприяє організації не тільки музичного 


\section{ФОРМУВАННЯ СВІТОГЛЯДУ ТВОРЧОЇ ОСОБИСТОСТІ В УМОВАХ ОСВІТНЬОГО ПРОСТОРУ УКРӒ̈НИ}

мислення, але й відчування у широкому естетичному значенні цього слова. Б. Яворський стверджував, що зміст заняття, до якого входить слухання музики, впливає на організацію творчої уваги, звільнення творчого сприйняття від зайвої напруги, а словесні оформлення слухової реакції вимагає від учнів серйозної аналітичної роботи [6, 182-183].

Виходячи із досліджень музично-педагогічного досвіду Б. Яворського можемо зробити висновок, що творча діяльність митця стали підгрунтям національної і світової музично-педагогічної освіти, формування високоморальної особистості.

Таким чином, особливості педагогічної діяльності і наукові праці визначних письменників, істориків, філософів, композиторів, музичних діячів вплинули на формування світогляду творчої особистості, а також становить важливу складову масиву історико-педагогічних досліджень, $є$ актуальними до сьогодні.

Висновки та перспективи подальших наукових розвідок. Підсумувавши отриману під час аналітичних розвідок інформацію, можна стверджувати, що формування світогляду творчої особистості в умовах освітнього простору України передбачає традиційний педагогічний досвід видатних митців, що сприяє освоєнню і трансляції спадщини педагогічної освіти і культури. За допомогою науково-методичної спадщини вітчизняних педагогів в освітньому просторі створюється позитивна ціннісна орієнтація навчання, тобто формується світогляд творчої особистості.

Перспективи дослідження проблеми пов'язані 3 пошуком шляхів упровадження ідей формування світогляду творчої особистості в умовах освітнього простору України.

\section{ЛITЕРАТУРА}

1. Верменич Я. Поняття "регіональна історія" як структурна модель територіальних досліджень. Регіональна історія України. Київ: Інститут історії України НАН, 2008. № 2. С. 9-28.

2. Коменда О. Кирило Стеценко: індивідуальний стиль як чинник творчого універсалізму. Науковий вісник Національної музичної академії України імені П. І. Чайковського. 2020. № 127. С. 7-26.

3. Коменский Я. Избранные педагогические сочинения в 2-х т. Москва: Педагогика, 1982. Т.2. 576 с.

4. Кремень В. Філософія: мислителі, ідеї, концепції. Підручник. Київ: Книга, 2005. 528 с.

5. Кузьменко Ю. Педагогічна спадщина В.О. Сухомлинського як чинник розвитку потреб у становленні професіоналізму педагогів. Педагогічний альманах, 2015. Випуск 26. С. 215-219.

6. Мартинюк А. Науково-педагогічна концепція Б.Яворського у контексті мистецької освіти. Молодь $i$ ринок №3-4 2020, С.182-183.
7. Неживий О. Борис Грінченко: Вартовий рідного слова. Педагогічна спадщина та проблеми сучасноі освіти. Луганськ: Знання, 2003. 124c.

8. Пашнев Б. Психодіагностика обдарованості. Практична психологія та сочіальна робота. Київ, $2005.322 \mathrm{c}$.

9. Чижевський Д. Нариси з історії філософії на Україні. Київ : “Орій” при УКСП “Кобза”, 1992.230 с.

10. Юрас І. Памфіл Данилович Юркевич. Персоналії в історії національної педагогіки. 22 видатних українських педагогів. Підручник. Київ : ВД “Професіонал”, 2004. С. 180-207.

\section{REFERENCES}

1. Vermenych, J. (2008). Ponyattya "rehionalna istoriya" yak strukturna model terytorialnykh doslidzhen [The concept of "regional history" as a structural model of territorial research]. Regional history of Ukraine. Kyiv, No. 2. pp. 9-28. [in Ukrainian].

2. Komenda, O. (2020). Kyrylo Stetsenko: indyvidualnyy styl yak chynnyk tvorchoho universalizmu [Kyrylo Stetsenko: individual style as a factor of creative universalism]. Scientific Bulletin of the Tchaikovsky National Academy of Music of Ukraine. No. 127. pp. 7 26. [in Ukrainian].

3. Komensky, J. (1982). Yzbrannye pedahohycheskye sochynenyya $\mathrm{v} 2$-kh tomakh [Selected pedagogical works in 2 volumes]. Moscow, Vol. 2. 576 p. [in Russian].

4. Kremen, V. (2005). Filosofiya: myslyteli, ideyi, kontseptsiyi [Philosophy: thinkers, ideas, concepts]. Textbook. Kyiv, 528 p. [in Ukrainian].

5. Kuzmenko, Y. (2015). Pedahohichna spadshchyna V.O. Sukhomlynskoho yak chynnyk rozvytku potreb u stanovlenni profesionalizmu pedahohiv [Pedagogical heritage V.O. Sukhomlinsky as a factor in the development of needs in the formation of professionalism of teachers]. Pedagogical Almanac. Issue 26. pp.215-219. [in Ukrainian].

6. Martyniuk, A. (2020). Naukovo-pedahohichna kontseptsiya B.Yavorskoho u konteksti mystetskoyi osvity [Scientific and pedagogical concept of B. Yavorsky in the context of art education]. Youth \& market. No. 3-4. pp.182-183. [in Ukrainian].

7. Nezhyvyy, O. (2003). [Boris Grinchenko: Guardian of the native language]. Pedagogical heritage and problems of modern education. Lugansk, 124 p. [in Ukrainian].

8. Pashnev, B. (2005). Psykhodiahnostyka obdarovanosti [Psychodiagnostics of giftedness]. Practical Psychology and Social Work. Kyiv, 322 p. [in Ukrainian].

9. Chizhevsky, D. (1992). Narysy z istoriyi filosofiyi na Ukrayini [Essays on the history of philosophy in Ukraine]. Kyiv, 230 p. [in Ukrainian].

10. Yuras, I. (2004). Pamfil Danylovych Yurkevych. Personaliyi $\mathrm{v}$ istoriyi natsionalnoyi pedahohiky. 22 vydatnykh ukrayinskykh pedahohiv [Pamfil Danilovich Yurkevich. Personalities in the history of national pedagogy. 22 outstanding Ukrainian teachers]. Textbook. Kyiv, pp.180-207. [in Ukrainian].

Стаття надійшла до редакції 29.04.2021 